\title{
Analysis Of Risk Factors Of Mellitus Diabetes At Hospital H. Andi Sulthan Daeng Radja Bulukumba
}

\author{
Hardianti ${ }^{1}$, Haerani ${ }^{2}$, Amirullah ${ }^{3}$ \\ S1 Nursing Study Program, Stikes Panrita Husada Bulukumba, Indonesia ${ }^{1}$ \\ Departemen Community and Family Nursing , Stikes Panrita Husada Bulukumba, Indonesia ${ }^{2}$ \\ Departemen Mental Health Nursing, Stikes Panrita Husada Bulukumba ,Indonesia ${ }^{3}$
}

Corresponding Autor: ainunhaerani@yahoo.com

\begin{abstract}
ABSTRAK
Diabetes Mellitus (DM) is a health disorder in the form of a collection of symptoms caused by an increase in blood sugar (glucose) levels due to insulin deficiency or resistance. DM can cause complications such as hypertension, myocardial infarction, coronary insufficiency, diabetic retinopathy, cataracts, diabetic neuropathy, and others. Factors associated with diabetes mellitus are gender, age, genetic factors, obesity, hypertension, stress, cholesterol levels, and diet. From the results of a preliminary study conducted by researchers on July 25, 2018, with as many as 80 respondents, 40 respondents who experienced DM and 40 respondents who did not experience DM. The purpose of this study was to determine the factors associated with the incidence of diabetes mellitus in H.Andi Sulthan Hospital Daeng Radja Bulukumba in 2018 This study uses analytical design with a "case-control" approach. The population in this study is 228 people. The sample of this study were 80 respondents (40 respondents with DM and 40 respondents who were not DM) with a purposive sampling method. The results of the study were carried out using statistical tests obtained that gender, age, genetic factors, obesity, hypertension, stress, cholesterol levels, and dietary patterns are risk factors for diabetes mellitus which obtained by ( $p$-value $=<0.005$ ) so that it can be concluded that there is a relationship of gender, age, genetic factors, obesity, hypertension, stress, cholesterol levels and diet with the incidence of diabetes mellitus in H.Andi Sulthan Daeng Radja Bulukumba Hospital. It is recommended for hospitals to cooperate in promotive and preventive efforts by providing counseling or information media in the hospital environment.
\end{abstract}

Keywords: Risk Factors, Diabetes Mellitus Event

\section{INTRODUCTION}

Diabetes Mellitus (DM) is a group of metabolic diseases characterized by chronic hyperglycemia that occurs due to abnormal insulin secretion, insulin action, or both (PERKENI, 2015). The increase in the number of people with diabetes mellitus lately is very fast, and many of them do not realize how serious the disease is (Herlambang, 2013). WHO data reveal, the global burden of diabetes mellitus in 2000 was 135 million, where this burden is expected to continue to increase to 366 million people after 25 years (2025). (Herlambang, 2013). Indonesia ranks seventh in the world with diabetes mellitus the highest in the world after China, India, the United States, Brazil, Russia and 
Mexico with an estimated number of about 10 cases in 2015 (IDF, 2015). The prevalence of people with diabetes in Indonesia shows a tendency to increase from $5.7 \%$ in 2007 to $6.9 \%$ in 2016 (Riskesdas, 2016).

The increase in the incidence of diabetes mellitus in theory is inseparable from the risk factors that influence it, so that DM can also be prevented by controlling the risk factors (Ministry of Health, 2010). Other studies also conducted by Trisnawati and Soedijono (2012) with results showing that obesity, age $>45$ years, female sex, lack of physical activity, and hypertension are risk factors and have a significant relationship with the incidence of diabetes mellitus. Jelanti and Haryati (2014) also suggested that age, sex, obesity and hypertension could influence the incidence of diabetes mellitus.

Epidemiological research is still being carried out, the results of routine surveillance of hospital-based non-communicable diseases (PTM) in South Sulawesi in 2008, DM was included in the order of four non-communicable diseases (PTM) with a prevalence of 6.65\%. Even in 2010, the results of the South Sulawesi Provincial Health Office survey showed that Diabetes Mellitus (DM) was the highest cause of death (PTM) in South Sulawesi with a proportion of $41.56 \%$ (Fachruddin et al, 2013).

Based on data from the Health Department of Bulukumba Regency, the number of people with Diabetes Mellitus in 2012 was 1,243 people and those categorized as risky and routinely checked their sugar levels were 945 people (Dukes of Bulukumba District Health Office, 2012). And the prevalence of diabetes mellitus, especially hospitals HASultang Daeng Radja Bulukumba Regency tends to increase, from year to year, where obtained data from the Medical Record that the prevalence of DM in 2015 as many as 06 people, 2016 as many as 118 people and increased in 2017 as many as 228 people (Medical Records of Bulukumba Regional Hospital, 2018). The purpose of this study was to analyze whether there is a relationship between sex, age, genetic factors, obesity, hypertension, stress, cholesterol levels and diet with the incidence of diabetes mellitus in H.Andi Sulthan Daeng Radja Bulukumba Hospital in 2018.

\section{MATERIAL AND METHODS}

The research design used in this study was an observational analytic research design with a Case control approach because it wanted to know the analysis of risk factors for Diabetes Mellitus in H.Andi Sulthan Daeng Radja Bulukumba Hospital. Population is the total amount consisting of objects or subjects that have certain characteristics and qualities determined by researchers to be examined and then drawn 
conclusions (Setiadi, 2013). The population in this study were all inpatients at H.Andi Sulthan Daeng Radja Bulukumba Hospital. Sampling using a purposive sampling technique which is a technique of determining the sample by selecting samples among the population in accordance with what the researchers want. The number of samples in this study were 80 respondents.

The instrument used in this study was to use an observation sheet, with secondary data retrieval done by Bulukumba medical records. Data were analyzed based on measuring scale and research objectives using computerized program software. Data were analyzed by: (1). Univariate Analysis, Analysis is done to see the proportion. (2). Bivariate Analysis, Bivariate test is carried out to find the relationship between the independent variable and the dependent variable with the test used is chi-square when it meets the requirements, and cell merge and fisher's exact tests will be done as an alternative. The confidence interval taken was $95 \%$ and the accepted significance limit if $\mathrm{p}<0.05$.

RESULTS

Table 1. Frequency Distribution Based on respondent Characteristics

\begin{tabular}{|c|c|c|}
\hline Karakteristik responden & $\mathbf{N}$ & $\begin{array}{c}\text { Percentage } \\
\text { (\%) }\end{array}$ \\
\hline Gender & 21 & 26.3 \\
\hline Male & 59 & 73.8 \\
\hline \multicolumn{3}{|l|}{ Female } \\
\hline Age & 28 & 35.0 \\
\hline Late adulthood $36-45$ years & 52 & 65.0 \\
\hline \multicolumn{3}{|l|}{ The age of $46-75$ years old } \\
\hline Genetic factors & 41 & 51.3 \\
\hline There is & 39 & 48.8 \\
\hline \multicolumn{3}{|l|}{ No } \\
\hline Obesity & 42 & 52.5 \\
\hline Underweight 18-24 kg & 38 & 47.5 \\
\hline \multicolumn{3}{|l|}{ Overweight $>24 \mathrm{~kg}$} \\
\hline Hypertension & 42 & 52.5 \\
\hline Hypertension & 38 & 47.5 \\
\hline \multicolumn{3}{|l|}{ No hypertension } \\
\hline Stress & 69 & 86.3 \\
\hline Anxious & 11 & 13.8 \\
\hline \multicolumn{3}{|l|}{ No } \\
\hline Cholesterol level & 57 & 71.3 \\
\hline Height> $184-199 \mathrm{mg} / \mathrm{dl}$ & 23 & 28.8 \\
\hline \multicolumn{3}{|l|}{ Normal184-199 mg / dl } \\
\hline Dietary habit & 15 & 18.8 \\
\hline Enough & 65 & 81.3 \\
\hline \multicolumn{3}{|l|}{ Less } \\
\hline Amount & 80 & 100 \\
\hline
\end{tabular}




\section{COMPRABDNSIVE HABH GARE}

Based on (Table 1) shows that most of the female sex are 59 respondents or around (73.8\%), most of the elderly age are 52 respondents or around (65.0\%), most genetic factors with history. there are 41 respondents or around (51.3), most of them are obese with overweight 38 respondents or around (47.5\%), most respondents with hypertension are 42 respondents or around (52.5\%), most of the stressors are 69 respondents who experience anxiety or about (86.3\%), most of the cholesterol levels with a high category were 57 respondents or around (71.3\%), most eating patterns with less criteria were 65 respondents or around (81.3\%).

Table 2. Factors related to the incidence of diabetes mellitus

\begin{tabular}{|c|c|c|c|c|c|c|}
\hline \multirow{3}{*}{ Gender } & \multicolumn{4}{|c|}{ Diabetes Mellitus } & \multirow[t]{3}{*}{ Amount } & \multirow[t]{3}{*}{$\begin{array}{l}P \\
0.020\end{array}$} \\
\hline & \multicolumn{2}{|c|}{ Diabetes } & \multicolumn{2}{|c|}{ No Diabetes } & & \\
\hline & $\mathbf{N}$ & & $\mathbf{N}$ & $\%$ & & \\
\hline Male & 6 & $28.6 \%$ & 15 & $71.4 \%$ & 21 & \\
\hline Girl & 34 & $57.6 \%$ & 25 & $42.4 \%$ & 59 & \\
\hline Age & $\mathrm{N}$ & $\%$ & $\mathbf{n}$ & $\%$ & & \\
\hline Late adulthood & 1 & $3.6 \%$ & 27 & $96.4 \%$ & 28 & \\
\hline Old age & 39 & $75.0 \%$ & 13 & $25.0 \%$ & 52 & 0.000 \\
\hline Genetic Factor & $\mathbf{N}$ & $\%$ & $\mathrm{n}$ & $\%$ & & \\
\hline There is & 38 & $92.7 \%$ & 3 & 7.3 & 41 & 0.000 \\
\hline No & 2 & $5.1 \%$ & 37 & $94.9 \%$ & 39 & \\
\hline Obesity & $\mathbf{N}$ & $\%$ & $\mathrm{n}$ & $\%$ & & \\
\hline Under Weight 18-24 kg & 13 & $31.0 \%$ & 29 & $69.0 \%$ & & \\
\hline \multirow[t]{2}{*}{ Overweight $>24 \mathrm{~kg}$} & & & & & & \\
\hline & 27 & $71.0 \%$ & 11 & $28.9 \%$ & 38 & \\
\hline Hypertention & $\mathrm{N}$ & $\%$ & $\mathbf{n}$ & $\%$ & & \\
\hline Hipertensi & 31 & $73.8 \%$ & 11 & $26.2 \%$ & 42 & \\
\hline Tidak hipertensi & 9 & $23.7 \%$ & 29 & $76.3 \%$ & 38 & 0.000 \\
\hline Stress & $\mathrm{N}$ & $\%$ & $\mathrm{n}$ & $\%$ & & \\
\hline Anxious & 40 & $58.0 \%$ & 29 & $42.0 \%$ & 69 & \multirow{2}{*}{0.000} \\
\hline No & 0 & $0.0 \%$ & 11 & $100.0 \%$ & 11 & \\
\hline $\begin{array}{l}\text { Cholesterol Level } \\
\text { Height }>184-199 \mathrm{mg} / \mathrm{dl}\end{array}$ & $\begin{array}{l}\mathbf{N} \\
38\end{array}$ & $\begin{array}{l}\% \\
66.7 \%\end{array}$ & $\begin{array}{l}\mathbf{N} \\
19\end{array}$ & $\begin{array}{l}\% \\
33.0 \%\end{array}$ & & \\
\hline Normal184-199 mg / dl & 2 & $8.7 \%$ & 21 & $91.3 \%$ & 23 & \\
\hline Dietary Habit & $\mathrm{N}$ & $\%$ & $\mathbf{N}$ & $\%$ & & \\
\hline Enough & 1 & $6.7 \%$ & 14 & $93.0 \%$ & 15 & \multirow{2}{*}{0.000} \\
\hline Less & 39 & $60.0 \%$ & 26 & $40.0 \%$ & 65 & \\
\hline Amount & 40 & & 40 & & 80 & \\
\hline
\end{tabular}

Relationship between sex and the incidence of diabetes mellitus in H.Andi Sulthan Daeng Radja Bulukumba Hospital, there were 6 male respondents with DM or around (28.0\%) and those who did not experience DM in male sex were 15 people or around 
(71.4\%). While women who have diabetes mellitus are 34 people or around (57.6\%), while respondents who do not have DM in the female sex are 25 people or about (42.4\%). Based on the results of the SPSS analysis using the chi-square test the results obtained $\mathrm{p}$ value $=0.020$ So it can be concluded that there is a sex relationship with the incidence of Diabetes Mellitus in Bulukumba Regional Hospital in 2018.

The relationship of age with the incidence of diabetes mellitus in H.Andi Sulthan Daeng Radja Bulukumba Hospital in 2018, namely respondents with late adulthood who experienced DM as many as 1 person or about (3.6\%) and respondents who did not experience DM in late adulthood were 27 people or around (96.4\%). While the elderly who have diabetes mellitus as many as 39 people or around (75.0\%), and respondents who did not experience DM in the elderly as many as 13 people or about (25.0\%).

Based on the results of the SPSS analysis using the chi-square test results obtained $p$ value $=0.000$ So it can be concluded that there is a relationship between age and the incidence of Diabetes Mellitus in Bulukumba Regional Hospital in 2018.

The relationship of genetic factors with the incidence of diabetes mellitus in H.Andi Sulthan Daeng Radja Bulukumba Hospital in 2018: respondents with a history of offspring there were 38 people with DM or about (92.7\%) and respondents who did not experience DM in the history of offspring there were 3 people or around (7.3\%). While the history of offspring who did not have diabetes mellitus were 2 people or around (5.1\%), and respondents who did not have DM were 37 people or around (94.9\%).

Based on the results of the SPSS analysis using the chi-square test the results obtained $\mathrm{p}$ value $=0.000$ So it can be concluded that there is a relationship between genetic factors and the incidence of diabetes mellitus in Bulukumba Regional Hospital in 2018.

The relationship of obesity with the incidence of diabetes mellitus in H.Andi Sulthan Daeng Radja Bulukumba Hospital in 2018 is respondents with underweight experienced DM as many as 13 people or around (31.0\%) and respondents who did not experience DM in underweight were 29 people or around (69.0\%). While the history of overweight who experienced diabetes mellitus were 27 people or around (71.0\%), and respondents who did not have DM were 11 people or around (28.9\%).

Based on the results of the SPSS analysis using the chi-square test the results obtained $p$ value $=0.000$ So it can be concluded that there is a relationship of obesity with the incidence of Diabetes Mellitus in Bulukumba District Hospital in 2018. 
The relationship of hypertension with the incidence of diabetes mellitus in H.Andi Sulthan Daeng Radja Bulukumba Hospital in 2018, there were 20 respondents with hypertension who experienced DM or approximately (21.5\%) and respondents who did not experience DM in hypertension patients were 23 people or around (21.5\%). While patients who are not hypertensive who have diabetes mellitus are 20 people or around (18.5\%), and respondents who don't have DM are 17 people or about (18.5\%).

Based on the results of the SPSS analysis using the chi-square test the results obtained $\mathrm{p}$ value $=0,000$. So it can be concluded that there is a relationship of hypertension with the incidence of Diabetes Mellitus in Bulukumba District Hospital in 2018.

The relationship of stress with the incidence of diabetes mellitus in H.Andi Sulthan Daeng Radja Bulukumba Hospital in 2018, there were 40 people who were anxious about DM patients or about (58.0\%) and 29 non-DM patients who were anxious or 42 (42.0) \%). While patients who are not anxious who have diabetes mellitus are absent or around (0.0\%), and respondents who do not have DM and are not anxious are 11 people or around (100.0\%).

Based on the results of the SPSS analysis using the chi-square test results obtained $\mathrm{p}$ value $=0.000$ So that it can be concluded that there is a stress relationship with the incidence of Diabetes Mellitus in RSUD Bulukumba in 2018.

The relationship of cholesterol levels with the incidence of diabetes mellitus in H.Andi Sulthan Daeng Radja Bulukumba Hospital in 2018 is that respondents with high cholesterol levels in DM patients are 38 people or around (66.7\%) and respondents who are not DM patients with high cholesterol levels are 19 people or around (33.0\%). While patients with normal cholesterol levels who had diabetes mellitus were 2 people or around (8.7\%), and respondents who did not experience DM and had cholesterol levels within the normal range of 21 people or around (91.3\%).

Based on the results of the SPSS analysis using the chi-square test the results obtained $p$ value $=0.000$ So it can be concluded that there is a correlation between cholesterol levels and the incidence of Diabetes Mellitus in RSUD Bulukumba in 2018.

The relationship of eating patterns with the incidence of diabetes mellitus in H.Andi Sulthan Daeng Radja Bulukumba Hospital in 2018, namely respondents with adequate diet in DM patients as many as 1 person or about (6.7\%) and respondents who are not DM patients whose diet is enough as many as 14 people or around (93.0\%). While 
patients with poor diet have $39 \mathrm{DMs}$ or around (60.0\%), and 26 people who don't have DM and lack of eating patterns (40.0\%).

Based on the results of the SPSS analysis using the chi-square test the results obtained $p$ value $=0,000$. So it can be concluded that there is a relationship between eating patterns and the incidence of Diabetes Mellitus in Bulukumba Regional Hospital in 2018.

\section{DISCUSSION}

In this study it was seen that there was a significant relationship between sex, age, genetic factors, obesity, hypertension, stress, cholesterol levels and diet with the incidence of diabetes mellitus in H.Andi Sulthan Daeng Radja Bulukumba Hospital.

From the results of SPSS analysis using the chi-square test obtained p value $=0.020$ So it can be concluded that there is a relationship between female sex and the incidence of Diabetes Mellitus in Bulukumba Regional Hospital in 2018. This research is in line with research conducted by Zulkifli (2013) and Dewi Prasetyani (2017) in Prolanis Puskesmas Cilacap Tengah with a total sample of 69 respondents and most were female as many as 52 respondents with the results of a logistic regression test showing gender having a $p$-value $=<0.05$ so it can be concluded that there is a relationship of sex with incidence of diabetes mellitus with a value ( $p$-value $=0.018)$.

Based on the results of the SPSS analysis using the chi-square test obtained p-value $=0.000$ So it can be concluded that there is a relationship of age $>45$ years with the incidence of Diabetes Mellitus in Bulukumba Regional Hospital in 2018. This research is in line with research conducted by Igusti Made Geria Jelantik (2014), with the results of the Contingency $C$ coefficient test, it was found that the value of $p=0,000(p<0.05)$ showed a significant relationship between age $>45$ years and the incidence of Diabetes Mellitus in the working area of Mataram Public Health Center in 2012.

Based on the results of the SPSS analysis using the chi-square test obtained p-value $=0.000(\mathrm{a}<0.05)$, the hypothesis is accepted, so it can be concluded that there is a relationship between genetic factors and the incidence of Diabetes Mellitus in Bulukumba District Hospital in 2018. This research is in line with research conducted by Mariesla Y et al (2014) with the title research on the relationship of family history with the incidence of diabetes mellitus, with the analysis showing a p-value $=0,000$ which means there is a significant relationship between family history and the incidence of diabetes mellitus. 
Based on the results of the SPSS analysis using the chi-square test obtained p-value $=0,000(\mathrm{a}<0.05)$, the hypothesis is accepted so that it can be concluded that there is a relationship of obesity with the incidence of Diabetes Mellitus in H.Andi Sulthan Daeng Radja Bulukumba Hospital. with research conducted by Asmarani et al (2017) shows that there is a significant relationship between obesity and the incidence of diabetes mellitus which can be seen from the results of statistical test analysis, the OR value is 7,164 with a $95 \%$ confidence interval the OR value is at an interval of 3,365-15,250 which shows that the value between lower imit and upper limit is above 1 , then Ho is rejected so there is a significant relationship between the obesity variable and the incidence of diabetes mellitus.

Based on the results of the SPSS analysis using the chi-square test obtained p-value $=0,000(\mathrm{a}<0.05)$, the hypothesis is accepted so that it can be concluded that there is a relationship of hypertension with the incidence of Diabetes Mellitus in Bulukumba Regional Hospital in 2018. This study is in line with the research conducted by Jelantik and Haryati (2014) about the analysis of risk factors for the incidence of diabetes mellitus which shows that hypertension is a DM risk factor with a palue $=0,000$.

Based on the results of the SPSS analysis using the chi-square test obtained p-value $=0,000(\mathrm{a}<0.05)$, the hypothesis is accepted so it can be concluded that there is a stress relationship with the incidence of Diabetes Mellitus in Bulukumba District Hospital in 2018. This research is in line with the research conducted by Wisnatul (2015) in the Work Area of the Rasimah Ahmad Bukittnggi Urban Health Center with the results found that there is a significant relationship between stress and elevated blood sugar levels of patients with diabetes mellitus with a $\mathrm{p}$ value $=<0.005$ ( $\mathrm{p}=$ 0.017).

Based on the results of the SPSS analysis using the chi-square test obtained p-value $=0,000(\mathrm{a}<0.05)$, the hypothesis is accepted so it can be concluded that there is a correlation between cholesterol levels and the incidence of Diabetes Mellitus in Bulukumba Regional Hospital in 2018. This research is in line with the research conducted by Melly Ana Sari (2016) which shows that the distribution of respondents based on high cholesterol levels has a significant relationship with the incidence of diabetes mellitus with a $\mathrm{p}$-value $=0,000$.

Based on the results of the SPSS analysis using the chi-square test obtained p-value $=0,000(\mathrm{a}<0.05)$, the hypothesis is accepted so it can be concluded that there is a 
relationship between eating patterns and the incidence of Diabetes Mellitus in Bulukumba Regional Hospital in 2018. This research is in line with the research conducted Suryadi Tjekyan (2014) in the Municipality of Palembang using a chi-square statistical test obtained $\mathrm{p}$ value $=0,000$ which means there is a relationship between diet and diabetes mellitus.

\section{CONCLUSIONS}

Based on the results of the study above, it was concluded that there was a significant relationship between sex, age, genetic factors, obesity, hypertension, stress, cholesterol levels, and diet with the incidence of diabetes mellitus in H.Andi Sulthan Daeng Radja Bulukumba Hospital. The results of this study hopefully can increase knowledge for students at STIKES Panrita Husada Bulukumba. And the hospital is expected to be able to work together in promoting and preventing efforts by providing counseling or information media in the hospital environment about diabetes.

\section{REFERENCES}

Trijayanto, P. A., \& Endiyono. (2017). Hubungan Riwayat Garis Keturunan Dengan Usia Terdiagnosa Diabetes Mellitus Tipe 2. University Research Coloquium .

ADA. (2015). Diagnosis and Classificaton of Diabetes Mellitus.

Asmarani, Tahir, dkk. (2017). Analisis Faktor Risiko Obesitas Dan Hipertensi Dengan Kejadian Diabetes Mellitus Tipe 2 Di RSUD Kota Kendari. Volume 4 Nomor 2.

Baradero, M. (2009). Asuhan Keperawatan Klien Gangguan endokrin. jakarta: EGC.

Chandra, Z. F.,Suryanto, \& T. R. (2007). Faktor-Faktor Risiko Pasien Diabetes Mellitus. Berita Kedokteran Masyarakat Volume 23 Nomor 3.

Dewi Prasetya.(2017). Analisis Faktor Yang Mempengaruhi Keadian Diabetes Mellitus Tipe 2. Jurnal Kesehatan AI Irsyad (JKA) Volume x Nomor 2.

Dharma, K. K. (2011). Metodologi Penelitian Keperawatan. Jakarta: CV. Trans Info Medika.

Frankilwati, D. A. (2014). Hubunga Antara Pola Makan, Genetik, Dan Kebiasaan Olahraga Terhadap Kejadian Diabetes Mellitus Tipe 2 Di Wilayah Kerja Puskesmas Nusuka Banjarmasin.

Geria Jelanti, I. M. (2014). Hubungan Faktor Risiko Umur, Jenis Kelamin, Kegemukan Dan Hipertensi Dengan Kejadian Diabetes Mellitus Tipe 2 Di Wilayah Kerja Puskesmas Mataram. Media Bina IImiah Volume 8 Nomor 1. 
Haryanti, J. d. (2014). Hubungan Faktor Risiko Usia, Jenis kelamin, kegemukan dan hipertensi dengan kejadian Diabetes Mellitus Tipe 2 di Wilayah Kerja

Puskesmas Mataram.

Haska, Y. (2017). Determinan Perilaku Pengendalian Diabetes Mellitus Di Wilayah Kota Makassar. Global Health Science Volume 2 Issue 2.

Hidayat, A. A. (2014). Metode Penelitian Keperawatan dan Tehnik Analisis Data. Jakarta: Salemba Medika.

Idris, A dkk. (2014). Hubungan Pola Makan Dengar Kadar Gula Darah Pasien Rawat Jalan DM Tipe 2 Di Wilayah Kerja Puskesmas Kota Makassar.

WHO (Word Health Organization. (2014). Diabetes Fakta dan Angka.

PERKENI. (2015). Konses Pengelolaan dan Pencegahan Diabetes Mellitus Tipe 2 di indonesia. jakarta..

RISKESDA. (2016). Profil Kesehatan Indonesia Tahun 2015.

Rumahorbo, H. (2014). Asuhan Keperawat Klien Dengan Gangguan Sistem Endokrin Jakarta: EGC.

Setiadi. (2013). Konsep Dan Praktik Penulisan Riset Keperawatan. Yokyakarta: Graha Ilmu.

Sujarweni, V. W. (2014). Metodologi Penelitian Keperawatan. Yokyakarta: Gava Media.

Sukmaningsih, W. R., \& Kasjono, H. S. (2014). Faktor Risiko Kejadian Diabetes Mellitus Tipe 2 Di Wilayah Keja Puskesmas Purwodiningratan Surakarta.

Tartowo. (2012). Keperawatan Medikal Bedah Gangguan Sistem Endokrin. Jakarta: Trans Info Media.

Tjekyan, R. S. (2014). Angka Kejadian Dan Faktor Risiko Diabetes Mellitus Tipe 2 Di 78 RT Kotamadya Palembang Tahun 2010. MKS, Th.46. No. 2, .

Trisnawati, dkk. (2013). Faktor Risiko Kejadian Diabetes Mellitus Tipe 2 Di Puskesmas Kecamatan Cengkareng Jakarta Barat Tahun 2012. Jurnal IImiah Kesehatan $5(1)$

Wisnatul izzati\& Nirmala. (2015). Hubungan Tingkat Stress Dengan Peningkatan Kadar Gula Darah Pada Pasien Diabetes Mellitus Di Wilayah Kerja Perkotaan Rasima Ahmad Bukitinggi.

Dinkes Kabupateng Bulukumba 2012

Fachruddin dkk.2013 PTM Sulawesi Selatan

Rakam Medis. 2017 Data Penyakit Diabetes Mellitus Di RSUD H.Andi Sulthan Daeng Radja Bulukumba 